\title{
ARTHRITIS AND RHEUMATISM IN THE INSURED POPULATION OF NORTHERN IRELAND
}

\author{
BY \\ C. W. KIDD \\ Ministry of Health and Local Government \\ A. T. PARK \\ Ministry of Finance, Northern Ireland
}

It is impossible to exaggerate the importance of the effect of the rheumatic diseases on the health and economy of the community. For many years those concerned with assessing the health of the nation have relied mainly on the Registrar General's mortality records in the absence of any reliable routine morbidity data. It is clear that, for the relatively non-fatal rheumatic diseases, such data give an inadequate measurement of the invalidism and human suffering involved.

It is not surprising that the problem of rheumatism in industry with its considerable loss of manpower should have attracted most attention and there is in fact little precise information available regarding the incidence in the general population.

The Department of Health for Scotland (1932-37) in pre-war studies reported that about 3 per cent. of the insured population were incapacitated annually because of "arthritis and rheumatism". The difference in the size and structure of the insured population since 1948 invalidates this source for purposes of comparison. Newman (1924) and others have reported that an almost similar percentage of the population consults the family doctors each year with rheumatic complaints which were found to be responsible for one-sixth of the total invalidism of the population. More recently Slater (1946) and Logan and Brooke (1957) have dealt with the records of the Survey of Sickness (1943-52). They indicate a monthly incidence of rheumatism in the general population of just under 20 per cent. This figure will include minor rheumatic conditions not severe enough to cause incapacity for work, and these statistics have the disadvantage of self-diagnosis. Logan and Cushion (1958) have discussed a valuable contribution to morbidity records-a joint study by the College of General Practitioners and the General Register Office. It was found that rheumatic disorders took second place in the list of conditions necessitating $\overrightarrow{\overrightarrow{0}}$ consultation in general practice $(64.9$ per thousand $i v$ population).

In the industrial field valuable studies have been reported by Lawrence and Aitken-Swan (1952), 을 Kellgren and Lawrence (1952), and Lawrence (1955). $\vec{c}$ Field studies were designed to compare the incidence of rheumatism in miners with that in the general $\widetilde{D}$ population. From their records it is demonstrated $\vec{\varphi}$ that rheumatic complaints are of frequent occug 8 rence in the general population, and that in mine the incidence of these conditions is no greater thati in the population as a whole. The degree of incapacity, however, is greater in miners in terms of loss of working time, and there is evidence of an $\frac{\circ}{\varnothing}$ earlier onset as shown by a higher incidence in the fourth decade.

In spite of advances in recent years in our understanding of chronic rheumatic diseases, the lack of diagnostic definition and the difficulty in precise clinical diagnosis, except in advanced and typical cases, has hampered progress. For this and other reasons it is obvious that morbidity statistics have 3 . limitations in comparison with the results of $\delta$ specially-designed field studies and their chief $₹$ value is to give a broad picture of the problem 0 involved. Here it should be noted that in the diagnostic list the following clinical entities are included in the group "arthritis and rheumatism": acute arthritis-pyogenic and non-pyogenic, rheu- o matoid arthritis and allied conditions, osteo- N arthritis and allied conditions, other specified and 이 unspecified forms of arthritis, muscular rheumatism, and rheumatism unspecified.

It is proposed to make some general observations $\stackrel{\circ}{=}$ using records of sickness statistics. In this con- of nexion, Stuart-Harris (1954) has shown that it is possible to use the analyses derived from National ${ }^{\circ}$ Insurance data as a basis for estimating the size of 
such a problem, in his case bronchitis. Digests of Statistics analysing certificates of incapacity are issued annually by the Ministry of Pensions and National Insurance and show, under fifty main diagnostic headings, the causes of incapacity for work for virtually the entire working population of Great Britain including both employed and selfemployed persons. This information is based on doctors' certificates issued for purposes of sickness benefit.

Separate and similar analyses are carried out in Northern Ireland by the Ministry of Labour and National Insurance with a much smaller population at risk. Using this data, Park and Kidd (1958), in a general study on morbidity in the insured population of Northern Ireland, have shown that in terms of the duration of spells of incapacity chronic rheumatism takes a high place and has a longer median duration than that experienced in Scotland. Kidd and Park (1959) have recently shown that this group of diseases makes a very substantial contribution to the long-term sickness problem in Northern Ireland.

Information is available on a 20 per cent. sample basis for four complete years (ending May 31, 1955, 1956,1957 , and 1958 respectively) in the form of new spells commencing each year, the duration of spells completed each year, and the number of spells lasting more than one year. The diagnoses are coded according to the fifty causes of the International Statistical Classification of Diseases.

It is appreciated that here there is diagnostic imprecision in that a group of diseases is covered by the diagnostic heading arthritis and rheumatism. However, bearing in mind this and other limitations of morbidity studies derived from National Insurance sources, it is felt that it is worth while to record statistical data relating to this clinical group.

Table I shows that the inception rates for this group are higher for men and married women than for other women. Although in men and other women the rates are relatively low in the under-30 age group, this is not the case with married women. The inception rates increase with age in men and other women up to age 40 and then become stable. In married women there is evidence that the rates are always higher but continue to increase with age. The rates for males aged 60 to 64 years and for married women aged 50 to 59 years show a marked fall in the course of the four years under review, but there is no evidence of a similar trend among the other women aged 50-59 years.

TABLE I

NUMBER OF NEW SPELLS AND INCEPTION RATES FOR ARTHRITIS AND RHEUMATISM NUMBER OF SPELLS OF SICKNESS PER 1,000 EXPOSED TO RISK, BY AGE GROUP AND SEX (20 PER CENT. SAMPLE)

\begin{tabular}{|c|c|c|c|c|c|c|c|c|c|}
\hline \multirow{2}{*}{$\begin{array}{c}\text { Sex and } \\
\text { Marital Status }\end{array}$} & \multirow{2}{*}{$\begin{array}{c}\text { Age } \\
\text { Group } \\
\text { (yrs) }\end{array}$} & \multicolumn{2}{|c|}{$1954 / 55$} & \multicolumn{2}{|c|}{$1955 / 56$} & \multicolumn{2}{|c|}{$1956 / 57$} & \multicolumn{2}{|c|}{$1957 / 58$} \\
\hline & & Spells & $\begin{array}{l}\text { Inception } \\
\text { Rates }\end{array}$ & Spells & $\begin{array}{l}\text { Inception } \\
\text { Rates }\end{array}$ & Spells & $\begin{array}{c}\text { Inception } \\
\text { Rates }\end{array}$ & Spells & $\begin{array}{c}\text { Inception } \\
\text { Rates }\end{array}$ \\
\hline \multirow[t]{2}{*}{ Men } & $\begin{array}{l}15-19 \\
20-29 \\
30-39 \\
40-49 \\
50-59 \\
60-64\end{array}$ & $\begin{array}{r}61 \\
233 \\
403 \\
544 \\
456 \\
208\end{array}$ & $\begin{array}{r}8 \cdot 6 \\
16 \cdot 8 \\
27 \cdot 6 \\
37 \cdot 0 \\
36 \cdot 5 \\
45 \cdot 2\end{array}$ & $\begin{array}{l}71 \\
288 \\
456 \\
600 \\
528 \\
187\end{array}$ & $\begin{array}{l}10 \cdot 0 \\
20 \cdot 7 \\
31 \cdot 2 \\
40 \cdot 9 \\
42 \cdot 2 \\
40 \cdot 7\end{array}$ & $\begin{array}{r}66 \\
275 \\
420 \\
604 \\
498 \\
180\end{array}$ & $\begin{array}{r}9 \cdot 2 \\
19 \cdot 8 \\
28 \cdot 6 \\
40 \cdot 8 \\
39 \cdot 8 \\
37 \cdot 5\end{array}$ & $\begin{array}{r}54 \\
240 \\
424 \\
553 \\
491 \\
167\end{array}$ & $\begin{array}{r}7 \cdot 3 \\
17 \cdot 1 \\
28 \cdot 6 \\
37 \cdot 9 \\
38 \cdot 4 \\
34 \cdot 0\end{array}$ \\
\hline & Total ... & 1,905 & $28 \cdot 3$ & 2,130 & $31 \cdot 6$ & 2,043 & $30 \cdot 1$ & 1,929 & $28 \cdot 2$ \\
\hline \multirow[t]{2}{*}{ Married Women } & $\begin{array}{l}15-19 \\
20-29 \\
30-39 \\
40-49 \\
50-59 \\
60-64\end{array}$ & $\begin{array}{r}5 \\
83 \\
49 \\
76 \\
82\end{array}$ & $\begin{array}{l}3 \overline{3} \cdot 2 \\
25 \cdot 8 \\
38 \cdot 0 \\
58 \cdot 6\end{array}$ & $\begin{array}{r}10 \\
104 \\
61 \\
82 \\
75\end{array}$ & $\begin{array}{l}-\overline{41 \cdot 6} \\
32 \cdot 1 \\
41 \cdot 0 \\
53 \cdot 6\end{array}$ & $\begin{array}{r}6 \\
80 \\
68 \\
114 \\
66\end{array}$ & $\begin{array}{l}2 \overline{8} \cdot 6 \\
40 \cdot 0 \\
60 \cdot 0 \\
47 \cdot 1\end{array}$ & $\begin{array}{r}9 \\
94 \\
61 \\
114 \\
67\end{array}$ & $\begin{array}{l}\overline{34 \cdot 8} \\
33 \cdot 9 \\
60 \cdot 0 \\
44 \cdot 7\end{array}$ \\
\hline & Total .. & 295 & $36 \cdot 9$ & 332 & $41 \cdot 5$ & 334 & $41 \cdot 8$ & 345 & $42 \cdot 6$ \\
\hline \multirow[t]{2}{*}{ Other Women } & $\begin{array}{l}15-19 \\
20-29 \\
30-39 \\
40-49 \\
50-59 \\
60-64\end{array}$ & $\begin{array}{l}72 \\
91 \\
47 \\
57 \\
69\end{array}$ & $\begin{array}{r}9 \cdot 9 \\
12.0 \\
15 \cdot 7 \\
21 \cdot 9 \\
24 \cdot 6\end{array}$ & $\begin{array}{r}108 \\
124 \\
54 \\
79 \\
78\end{array}$ & $\begin{array}{l}14 \cdot 8 \\
16 \cdot 3 \\
18 \cdot 0 \\
30 \cdot 4 \\
27 \cdot 9\end{array}$ & $\begin{array}{r}94 \\
104 \\
52 \\
69 \\
70\end{array}$ & $\begin{array}{l}12 \cdot 7 \\
13 \cdot 9 \\
17 \cdot 3 \\
26 \cdot 5 \\
25 \cdot 0\end{array}$ & $\begin{array}{r}86 \\
112 \\
53 \\
46 \\
87\end{array}$ & $\begin{array}{l}11 \cdot 6 \\
15 \cdot 8 \\
18 \cdot 3 \\
19 \cdot 2 \\
30 \cdot 0\end{array}$ \\
\hline & Total ... & 336 & $14 \cdot 4$ & 443 & $19 \cdot 0$ & 389 & $16 \cdot 7$ & 384 & $16 \cdot 9$ \\
\hline
\end{tabular}


The sex-marital ratios of inception rates given in Table II show that the overall rate for other women is about half that for men and less than half that for married women, although the variations with age are appreciable. The overall rate for married women is about one and one half times greater than that for men, but it is double the rate for men between the ages of 20 and 29 years.
Table III, giving the duration of completed spells for arthritis and rheumatism, by sex, shows that in men and in other women only about 40 per cent. of spells last less than 3 weeks against 33 per cent. for married women, and the proportion lasting more than one year is significantly greater for both $\stackrel{5}{9}$ married and other women than for men in those $\overline{0}$ earlier years but is similar for $1957 / 58$.

TABLE II

RATIOS OF INCEPTION RATES FOR ARTHRITIS AND RHEUMATISM FOR THE THREE SEX-MARITAL GROUPS, BY AGE GROUP

\begin{tabular}{|c|c|c|c|c|c|c|c|c|c|c|c|c|}
\hline \multirow{3}{*}{$\begin{array}{c}\text { Age } \\
\text { Group }\end{array}$} & \multicolumn{3}{|c|}{$1954 / 55$} & \multicolumn{3}{|c|}{$1955 / 56$} & \multicolumn{3}{|c|}{$1956 / 57$} & \multicolumn{3}{|c|}{$1957 / 58$} \\
\hline & $\begin{array}{l}\text { Married } \\
\text { Women }\end{array}$ & $\begin{array}{l}\text { Other } \\
\text { Women }\end{array}$ & $\begin{array}{l}\text { Married } \\
\text { Women }\end{array}$ & $\begin{array}{l}\text { Married } \\
\text { Women }\end{array}$ & $\begin{array}{l}\text { Other } \\
\text { Women }\end{array}$ & $\begin{array}{l}\text { Married } \\
\text { Women }\end{array}$ & $\begin{array}{l}\text { Married } \\
\text { Women }\end{array}$ & $\begin{array}{l}\text { Other } \\
\text { Women }\end{array}$ & $\begin{array}{l}\text { Married } \\
\text { Women }\end{array}$ & $\begin{array}{l}\text { Married } \\
\text { Women }\end{array}$ & $\begin{array}{l}\text { Other } \\
\text { Women }\end{array}$ & $\begin{array}{l}\text { Married } \\
\text { Women }\end{array}$ \\
\hline & Men & Men & $\begin{array}{l}\text { Other } \\
\text { Women }\end{array}$ & Men & Men & $\begin{array}{l}\text { Other } \\
\text { Women }\end{array}$ & Men & Men & $\begin{array}{l}\text { Other } \\
\text { Women }\end{array}$ & Men & Men & $\begin{array}{l}\text { Other } \\
\text { Women }\end{array}$ \\
\hline $\begin{array}{l}15-19 \\
20-29 \\
30-39 \\
40-49 \\
50-59\end{array}$ & $\begin{array}{l}-\overline{2 \cdot 0} \\
0.9 \\
1.0 \\
1.6\end{array}$ & $\begin{array}{l}1.2 \\
0.7 \\
0.6 \\
0.6 \\
0.5\end{array}$ & $\begin{array}{l}-2 \cdot 8 \\
1 \cdot 6 \\
1 \cdot 7 \\
2 \cdot 4\end{array}$ & $\begin{array}{l}-\overline{2 \cdot 0} \\
1 \cdot 0 \\
1 \cdot 0 \\
1 \cdot 3\end{array}$ & $\begin{array}{l}1 \cdot 5 \\
0.8 \\
0.6 \\
0.7 \\
0.7\end{array}$ & $\begin{array}{l}-\overline{2 \cdot 6} \\
1 \cdot 8 \\
1 \cdot 3 \\
1 \cdot 9\end{array}$ & $\begin{array}{l}-1 \cdot 4 \\
1 \cdot 4 \\
1 \cdot 5 \\
1 \cdot 2\end{array}$ & $\begin{array}{l}1.4 \\
0.7 \\
0.6 \\
0.6 \\
0.6\end{array}$ & $\begin{array}{l}\overline{2 \cdot 1} \\
2 \cdot 3 \\
2 \cdot 3 \\
1 \cdot 9\end{array}$ & $\begin{array}{l}-\overline{2 \cdot 0} \\
1 \cdot 2 \\
1 \cdot 6 \\
1 \cdot 2\end{array}$ & $\begin{array}{l}1 \cdot 6 \\
0.9 \\
0 \cdot 6 \\
0 \cdot 5 \\
0 \cdot 8\end{array}$ & $\begin{array}{l}\overline{2 \cdot 2} \\
1 \cdot 9 \\
3 \cdot 1 \\
1 \cdot 5\end{array}$ \\
\hline All Ages & $1 \cdot 3$ & 0.5 & $2 \cdot 6$ & $1 \cdot 3$ & 0.6 & $2 \cdot 2$ & $1 \cdot 4$ & 0.6 & $2 \cdot 5$ & $1 \cdot 5$ & 0.6 & $2 \cdot 5$ \\
\hline
\end{tabular}

TABLE III

DURATION OF COMPLETED SPELLS FOR ARTHRITIS AND RHEUMATISM, BY SEX (20 PER CENT. SAMPLE)

\begin{tabular}{|c|c|c|c|c|c|c|c|c|c|c|c|c|c|}
\hline \multirow[b]{2}{*}{$\begin{array}{c}\text { Sex } \\
\text { and } \\
\text { Marital } \\
\text { Status }\end{array}$} & \multirow[b]{2}{*}{$\underset{\text { (days) }}{\text { Duration }}$} & \multicolumn{3}{|c|}{$1954 / 55$} & \multicolumn{3}{|c|}{$1955 / 56$} & \multicolumn{3}{|c|}{$1956 / 57$} & \multicolumn{3}{|c|}{$1957 / 58$} \\
\hline & & Spells & $\begin{array}{c}\text { Per- } \\
\text { centage } \\
\text { of } \\
\text { Total }\end{array}$ & $\begin{array}{c}\text { Cumu- } \\
\text { lative } \\
\text { Per- } \\
\text { centage }\end{array}$ & Spells & $\begin{array}{c}\text { Per- } \\
\text { centage } \\
\text { of } \\
\text { Total }\end{array}$ & $\begin{array}{l}\text { Cumu- } \\
\text { lative } \\
\text { Per- } \\
\text { centage }\end{array}$ & Spells & $\begin{array}{c}\text { Per- } \\
\text { centage } \\
\text { of } \\
\text { Total }\end{array}$ & $\begin{array}{c}\text { Cumu- } \\
\text { lative } \\
\text { Per- } \\
\text { centage }\end{array}$ & Spells & $\begin{array}{c}\text { Per- } \\
\text { centage } \\
\text { of } \\
\text { Total }\end{array}$ & $\begin{array}{c}\text { Cumu } \\
\text { lative } \\
\text { Per- } \\
\text { centage }\end{array}$ \\
\hline \multirow[t]{2}{*}{ Men } & $\begin{array}{c}1-3 \\
4-6 \\
7-12 \\
13-18 \\
19-24 \\
25-48 \\
49-78 \\
79-156 \\
157-312 \\
312 \\
\end{array}$ & $\begin{array}{r}15 \\
127 \\
324 \\
311 \\
245 \\
446 \\
177 \\
134 \\
55 \\
56\end{array}$ & $\begin{array}{r}0 \cdot 8 \\
6 \cdot 7 \\
17 \cdot 1 \\
16 \cdot 5 \\
13 \cdot 0 \\
23 \cdot 6 \\
9 \cdot 4 \\
7 \cdot 1 \\
2.9 \\
2 \cdot 9\end{array}$ & $\begin{array}{r}0 \cdot 8 \\
7 \cdot 5 \\
24 \cdot 6 \\
41 \cdot 1 \\
54 \cdot 1 \\
77 \cdot 7 \\
87 \cdot 1 \\
94 \cdot 2 \\
97 \cdot 1 \\
100 \cdot 0\end{array}$ & $\begin{array}{r}15 \\
146 \\
335 \\
321 \\
255 \\
529 \\
225 \\
144 \\
51 \\
48\end{array}$ & $\begin{array}{r}0 \cdot 7 \\
7 \cdot 1 \\
16 \cdot 2 \\
15 \cdot 5 \\
12 \cdot 3 \\
25 \cdot 6 \\
10 \cdot 9 \\
6 \cdot 9 \\
2 \cdot 5 \\
2 \cdot 3\end{array}$ & $\begin{array}{r}0 \cdot 7 \\
7 \cdot 8 \\
24 \cdot 0 \\
39 \cdot 5 \\
51 \cdot 8 \\
77 \cdot 4 \\
88 \cdot 3 \\
95 \cdot 2 \\
97 \cdot 7 \\
100 \cdot 0\end{array}$ & $\begin{array}{r}11 \\
170 \\
368 \\
332 \\
269 \\
570 \\
171 \\
138 \\
56 \\
71\end{array}$ & $\begin{array}{r}0 \cdot 5 \\
7 \cdot 9 \\
17 \cdot 1 \\
15 \cdot 4 \\
12 \cdot 5 \\
26 \cdot 4 \\
7 \cdot 9 \\
6 \cdot 4 \\
2 \cdot 6 \\
3 \cdot 3\end{array}$ & $\begin{array}{r}0 \cdot 5 \\
8 \cdot 4 \\
25 \cdot 5 \\
40 \cdot 9 \\
53 \cdot 4 \\
79 \cdot 8 \\
87 \cdot 7 \\
94 \cdot 1 \\
96 \cdot 7 \\
100 \cdot 0\end{array}$ & $\begin{array}{r}23 \\
189 \\
349 \\
311 \\
242 \\
504 \\
153 \\
108 \\
43 \\
61\end{array}$ & $\begin{array}{r}1 \cdot 2 \\
9 \cdot 5 \\
17 \cdot 6 \\
15 \cdot 7 \\
12 \cdot 2 \\
25 \cdot 4 \\
7 \cdot 7 \\
5 \cdot 4 \\
2 \cdot 2 \\
3 \cdot 1\end{array}$ & $\begin{array}{r}1 \cdot 2 \\
10 \cdot 7 \\
28 \cdot 3 \\
44 \cdot 0 \\
56 \cdot 2 \\
81 \cdot 6 \\
89 \cdot 3 \\
94 \cdot 7 \\
96 \cdot 9 \\
100 \cdot 0\end{array}$ \\
\hline & Total & 1,890 & $100 \cdot 0$ & & 2,069 & $100 \cdot 0$ & & 2,156 & $100 \cdot 0$ & & 1,983 & $100 \cdot 0$ & \\
\hline \multirow[t]{2}{*}{$\begin{array}{l}\text { Married } \\
\text { Women }\end{array}$} & $\begin{array}{c}1-3 \\
4-6 \\
7-12 \\
13-18 \\
19-24 \\
25-48 \\
49-78 \\
79-156 \\
157-312 \\
312 \\
\end{array}$ & $\begin{array}{l}1 \\
15 \\
40 \\
37 \\
34 \\
66 \\
36 \\
33 \\
13 \\
17\end{array}$ & $\begin{array}{r}0 \cdot 3 \\
5 \cdot 1 \\
13 \cdot 7 \\
12 \cdot 7 \\
11 \cdot 7 \\
22 \cdot 6 \\
12 \cdot 3 \\
11 \cdot 3 \\
4 \cdot 5 \\
5 \cdot 8\end{array}$ & $\begin{array}{r}0 \cdot 3 \\
5 \cdot 4 \\
19 \cdot 1 \\
31 \cdot 8 \\
43 \cdot 5 \\
66 \cdot 1 \\
78 \cdot 4 \\
89 \cdot 7 \\
94 \cdot 2 \\
100 \cdot 0\end{array}$ & $\begin{array}{l}1 \\
16 \\
45 \\
37 \\
39 \\
59 \\
43 \\
50 \\
19 \\
18\end{array}$ & $\begin{array}{r}0 \cdot 3 \\
4 \cdot 9 \\
13 \cdot 8 \\
11 \cdot 3 \\
11 \cdot 9 \\
18 \cdot 1 \\
13 \cdot 1 \\
15 \cdot 3 \\
5 \cdot 8 \\
5 \cdot 5\end{array}$ & $\begin{array}{r}0 \cdot 3 \\
5 \cdot 2 \\
19 \cdot 0 \\
30 \cdot 3 \\
42 \cdot 2 \\
60 \cdot 3 \\
73 \cdot 4 \\
88 \cdot 7 \\
94 \cdot 5 \\
100 \cdot 0\end{array}$ & $\begin{array}{l}1 \\
16 \\
56 \\
61 \\
49 \\
77 \\
40 \\
30 \\
25 \\
22\end{array}$ & $\begin{array}{r}0 \cdot 3 \\
4 \cdot 2 \\
14 \cdot 9 \\
16 \cdot 2 \\
13 \cdot 0 \\
20 \cdot 4 \\
10 \cdot 6 \\
8 \cdot 0 \\
6 \cdot 6 \\
5 \cdot 8\end{array}$ & $\begin{array}{r}0 \cdot 3 \\
4 \cdot 5 \\
19 \cdot 4 \\
35 \cdot 6 \\
48 \cdot 6 \\
69 \cdot 0 \\
79 \cdot 6 \\
87 \cdot 6 \\
94 \cdot 2 \\
100 \cdot 0\end{array}$ & $\begin{array}{r}6 \\
23 \\
49 \\
50 \\
38 \\
102 \\
28 \\
35 \\
14 \\
11\end{array}$ & $\begin{array}{r}1 \cdot 7 \\
6 \cdot 5 \\
13 \cdot 8 \\
14 \cdot 0 \\
10 \cdot 7 \\
28 \cdot 6 \\
7.9 \\
9 \cdot 8 \\
3.9 \\
3 \cdot 1\end{array}$ & $\begin{array}{r}1 \cdot 7 \\
8 \cdot 2 \\
22 \cdot 0 \\
36 \cdot 0 \\
46 \cdot 7 \\
75 \cdot 3 \\
83 \cdot 2 \\
93 \cdot 0 \\
96 \cdot 9 \\
100 \cdot 0\end{array}$ \\
\hline & Total & 292 & $100 \cdot 0$ & & 327 & $100 \cdot 0$ & & 377 & $100 \cdot 0$ & & 356 & $100 \cdot 0$ & \\
\hline \multirow[t]{2}{*}{$\begin{array}{l}\text { Other } \\
\text { Women }\end{array}$} & $\begin{array}{c}1-3 \\
4-6 \\
7-12 \\
13-18 \\
19-24 \\
25-48 \\
49-78 \\
79-156 \\
157-312 \\
312\end{array}$ & $\begin{array}{r}4 \\
18 \\
76 \\
56 \\
37 \\
59 \\
45 \\
27 \\
7 \\
29\end{array}$ & $\begin{array}{r}1 \cdot 1 \\
5 \cdot 0 \\
21 \cdot 2 \\
15 \cdot 6 \\
10 \cdot 3 \\
16 \cdot 5 \\
12 \cdot 6 \\
7 \cdot 6 \\
2 \cdot 0 \\
8 \cdot 1\end{array}$ & $\begin{array}{r}1 \cdot 1 \\
6 \cdot 1 \\
27 \cdot 3 \\
42 \cdot 9 \\
53 \cdot 2 \\
69 \cdot 7 \\
82 \cdot 3 \\
89 \cdot 9 \\
91 \cdot 9 \\
100 \cdot 0\end{array}$ & $\begin{array}{l}4 \\
23 \\
64 \\
65 \\
43 \\
85 \\
43 \\
39 \\
16 \\
15\end{array}$ & $\begin{array}{l}1 \cdot 0 \\
5 \cdot 8 \\
16 \cdot 1 \\
16 \cdot 4 \\
10 \cdot 8 \\
21 \cdot 4 \\
10 \cdot 8 \\
9 \cdot 8 \\
4 \cdot 1 \\
3 \cdot 8\end{array}$ & $\begin{array}{r}1 \cdot 0 \\
6 \cdot 8 \\
22 \cdot 9 \\
39 \cdot 3 \\
50 \cdot 1 \\
71 \cdot 5 \\
82 \cdot 3 \\
92 \cdot 1 \\
96 \cdot 2 \\
100 \cdot 0\end{array}$ & $\begin{array}{r}4 \\
33 \\
80 \\
54 \\
38 \\
106 \\
44 \\
38 \\
20 \\
26\end{array}$ & $\begin{array}{r}0 \cdot 9 \\
7 \cdot 4 \\
18 \cdot 1 \\
12 \cdot 2 \\
8 \cdot 6 \\
23 \cdot 9 \\
9 \cdot 9 \\
8 \cdot 6 \\
4 \cdot 5 \\
5 \cdot 9\end{array}$ & $\begin{array}{r}0 \cdot 9 \\
8 \cdot 3 \\
26 \cdot 4 \\
38 \cdot 6 \\
47 \cdot 2 \\
71 \cdot 1 \\
81 \cdot 0 \\
89 \cdot 6 \\
94 \cdot 1 \\
100 \cdot 0\end{array}$ & $\begin{array}{l}5 \\
31 \\
88 \\
60 \\
48 \\
97 \\
24 \\
19 \\
10 \\
13\end{array}$ & $\begin{array}{r}1 \cdot 3 \\
7 \cdot 8 \\
22 \cdot 3 \\
15 \cdot 2 \\
12 \cdot 2 \\
24 \cdot 5 \\
6 \cdot 1 \\
4 \cdot 8 \\
2 \cdot 5 \\
3 \cdot 3\end{array}$ & $\begin{array}{r}1 \cdot 3 \\
9 \cdot 1 \\
31 \cdot 4 \\
46 \cdot 6 \\
58 \cdot 8 \\
83 \cdot 3 \\
89 \cdot 4 \\
94 \cdot 2 \\
96 \cdot 7 \\
100 \cdot 0\end{array}$ \\
\hline & Total & 358 & $100 \cdot 0$ & & 397 & $100 \cdot 0$ & & 443 & $100 \cdot 0$ & & 395 & $100 \cdot 0$ & \\
\hline
\end{tabular}


Table IV shows that the number of spells lasting more than one year are centred in the older age groups, and it is of interest to note that (in contrast to the inception rates) these overall long-term spells per 1,000 persons exposed to risk are higher for other women than for men. This is probably due to the large proportion of other women in the younger age groups where the inception rates are low. The overall rate for married women is more than double that for either men or other women. Here the age-specific rates are of much interest.

For the last year under review it was possible to extract the arthritis and rheumatism cases for the Belfast Local Office area of the Ministry of Labour for comparison with the experience in the rest of the Province. Unfortunately an age and sex distribution of the population exposed to risk in the Belfast area was not available - only the totals for men and for women.

The inception rates per 1,000 exposed to risk for spells commencing during the year were as follows:

\begin{tabular}{|c|c|c|c|c|}
\hline \multirow{2}{*}{\multicolumn{3}{|c|}{ Area }} & \multicolumn{2}{|c|}{ Sex } \\
\hline & & & \multirow{2}{*}{$\begin{array}{l}\text { Men } \\
17 \cdot 4 \\
39 \cdot 0\end{array}$} & \multirow{2}{*}{$\begin{array}{c}\text { Women } \\
21 \cdot 7 \\
24 \cdot 1\end{array}$} \\
\hline $\begin{array}{l}\text { Belfast } \\
\text { Rest of Province }\end{array}$ & 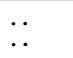 & $\begin{array}{l}. \\
.\end{array}$ & & \\
\hline Whole of Norther & reland & .. & $28 \cdot 2$ & $22 \cdot 8$ \\
\hline
\end{tabular}

The number of spells lasting more than one year per 1,000 exposed to risk were as follows:

\begin{tabular}{|c|c|c|c|c|c|}
\hline \multirow{2}{*}{\multicolumn{4}{|c|}{ Area }} & \multicolumn{2}{|c|}{ Sex } \\
\hline & & & & \multirow{2}{*}{$\begin{array}{r}\text { Men } \\
\begin{array}{l}1 \cdot 0 \\
\mathbf{3} \cdot \mathbf{8}\end{array}\end{array}$} & \multirow{2}{*}{$\begin{array}{c}\text { Women } \\
\begin{array}{c}2 \cdot 8 \\
4 \cdot 3\end{array}\end{array}$} \\
\hline $\begin{array}{l}\text { Belfast } \ddot{\text { Rest of Province }} \\
\text {. }\end{array}$ & 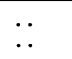 & 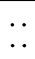 & 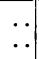 & & \\
\hline Whole of Norther & reland & $\ldots$ & $\ldots$ & $2 \cdot 7$ & $3 \cdot 5$ \\
\hline
\end{tabular}

In considering the reasons for this striking difference for men in the two areas, one has to consider, among other things, the age and sex differential of those exposed to risk in the two areas and the differing occupational backgrounds and social conditions.

While the Tables largely confirm clinical impressions regarding age incidence and chronicity, a striking and unexpected feature is the relatively high incidence of this disease group in married women compared with other women and with men, notably in the age group 20-29 years. This may well reflect only the high incidence of sickness generally amongst married women as a class which was shown by Park and Kidd (1958). It is possible that some of this sickness absence is due to social or domestic causes rather than to clinical disability, and it may be that "rheumatism" in a proportion of cases is a conventional diagnostic label.

TABLE IV

NUMBER OF SPELLS OF ARTHRITIS AND RHEUMATISM LASTING MORE THAN A YEAR, BY AGE GROUP, AND SEX AND RATE PER 1,000 EXPOSED TO RISK

(20 PER CENT. SAMPLE)

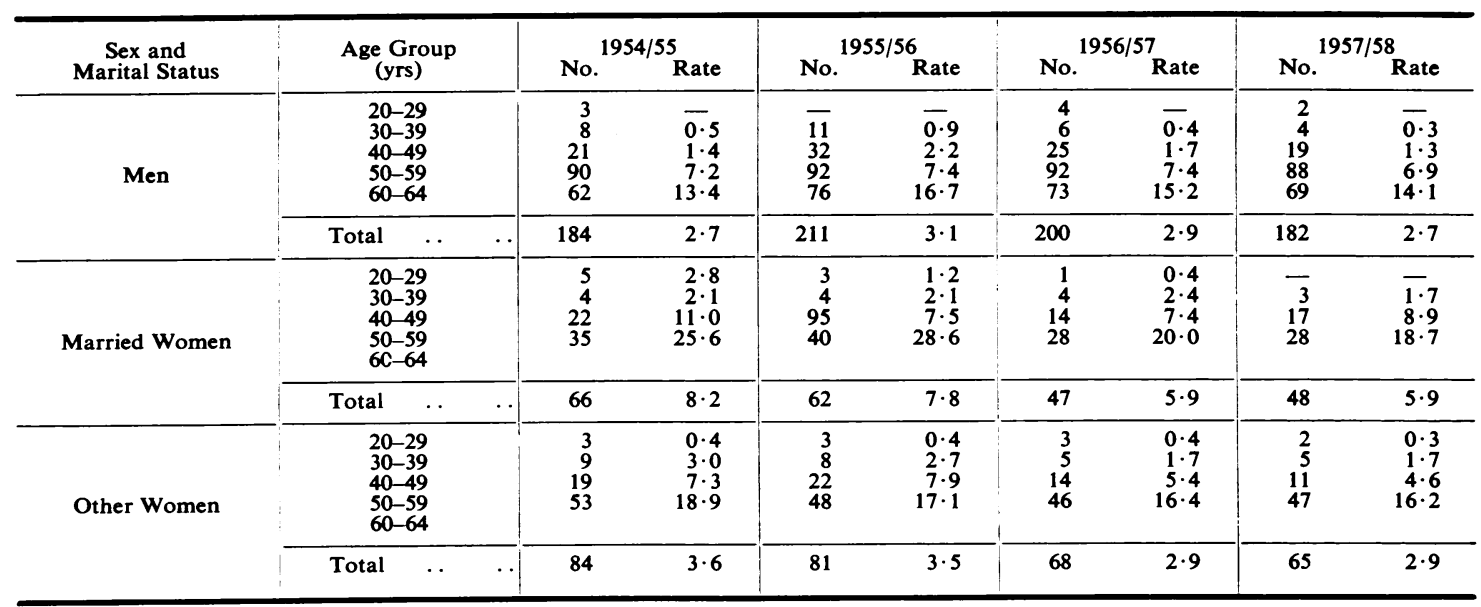


Climatic conditions in Northern Ireland with its high rainfall may be considered by some to have an influence on the incidence of arthritis and rheumatism, but this is a factor difficult to measure. Occupation as an influence is also highly relevant and it is hoped that a general survey of morbidity by occupation will be possible using data from the 1961 population census of Northern Ireland as the basis of the population exposed to risk.

\section{Comment}

This study gives a broad indication of the size of this disease group in the insured working population of Northern Ireland.

From a purely economic point of view the chronic rheumatic diseases are one of the major causes of absenteeism in industry. In Great Britain it is said that almost 28 million days are lost annually through these diseases at a cost to industry of $£ 80$ million. These figures, produced by the Empire Rheumatism Council, are significant only in indicating the economic size of the problem. In Northern Ireland it is felt that the situation is proportionately as great as in Great Britain. In the year ending May 31, 1958, it is estimated that chronic rheumatism accounted for $1,030,000$ working days lost to industry. This is a heavy and significant burden on the economy of a small community such as Northern Ireland.

We are indebted to Dr. E. A. Cheeseman, Department of Social and Preventive Medicine, Queen's University of Belfast, for his advice and help, and to Dr. F. F. Main, Chief Medical Officer, Ministry of Health and Local Government, for permission to publish this paper.

\section{REFERENCES}

Department of Health for Scotland (1932-37). "Report on Incapacitating Sickness in the Insured Population of Scotland", 1930-1936. H.M.S.O., Edinburgh.

Kellgren. J. H., and Lawrence, J. S. (1952). Brit. J. industr. Med., 9, 197.

Kidd, C. W., and Park, A. T. (1959). Med. Offr., 101, 327.

Lawrence, J. S. (1955). Brit. J. industr. Med., 12, 249.

and Aitken-Swan, J. (1952). Ibid., 9, 1 .

Logan, W. P. D., and Brooke, E. M." (1957). "General Register Office: Studies on Medical and Population Subjects", No. 12 H.M.S.O., London.
Logan, W. P. D. and Cushion, A. A. (1958). "Studies on Medical and Population Subjects", No. 14. H.M.S.O., London.

Newman, G. (1924). "Ministry of Health: Reports on Public Health and Medical Subjects", No. 23. H.M.S.O., London.

Park, A. T., and Kidd, C. W. (1958). Brit. J. prev. soc. Med., 12, 75.

Slater, P. (1946). "Survey of Sickness, 1943-45" [The Social Survey] H.M.S.O., London.

Stuart-Harris, C. H. (1954). Brit. J. Tuberc., 48, 169.

\section{Arthrite et rhumatisme parmi la population de l'Irlande du Nord \\ RÉSUMÉ}

Cette étude offre une indication générale de l'importance de ce groupe de maladies parmi la population ouvrière assurée de l'Irlande du Nord. La fréquence élevée de ces maladies chez des hommes de la région de Belfast, où réside à peu près la moitié de la population de l'Irlande du Nord, par rapport à celle chez des hommes du reste du pays, est significative. Tandis que les tables de morbidité, durée et incapacité prolongée confirment en général les impressions médicales concernant l'âge, la fréquence et la chronicité, on est frappé par le nombre relativement élevé des ouvrières mariées, surtout de celles âgées de 20 à 29 ans, parmi les malades. Cela pourrait bien réfléchir seulement la fréquence élevée de la maladie en général parmi des femmes mariées, fait mentionné dans un article antérieur. Certaines de ces absences du travail pourraient bien être dues à des raisons sociales et de famille plutôt qu'à l'incapacité d'ordre pathologique.

\section{Artritis y reumatismo entre la población asegurada de Irlanda del Norte \\ Sumario}

Este artículo presenta una indicación general de la frecuencia de este grupo de enfermedades entre la pob lación obrera asegurada de Irlanda del Norte. La elevada incidencia de estas enfermedades entre adultos varones en el area de Belfast, donde reside alrededor de la mitad de la población asegurada de Irlanda del Norte, en comparación con la encontrada entre los varones del resto del pais es significativa. Mientras que los valores en cuanto a comienzo, duración e incapacidad temporal confirman las impresiones clínicas respecto a edad, incidencia y cronicidad, es de lo más llamativo la relativamente alta frecuencia de presentación de este grupo de enfermedades entre las trabajadoras casadas, especialmente entre aquellas con una edad comprendida entre 20 y 29 años. Esto podía muy bien ser un reflejo solamente de la alta incidencia de enfermedades entre las mujeres casadas, lo que fué señalado en una publicación anterior. Algunas de estas ausencias del trabajo podian obedecer más a causas sociales y domésticas que a incapacidad patológica. 